\title{
VAN-E REGIONÁLIS KÖZGAZDASÁGTAN?
}

\author{
Szaló Péter
}

Magánügy-e vajon, hogy egy tanácskozás résztvevôje nem mondja el gondolatait a tárgy ról, az elhangzott véleményekról? Általában annak tekintjük. Vannak személyes okok, melyek bárkit visszatarthatnak a hozzászólástól. A kérdés ezzel le is záródhatna, ha nem lenne más lehetséges válasz. De van, és ez a lehetséges válasz kényszerít írásra! Mégpedig a cselekvéssel járó kijelentés, a hallgatásban rejlố elfogadás! Az ottlétet a benne rejlố kommunikáció közüggyé, közszerepléssé is avatja, és ez az amit tisztázni szeretnék, cáfolni a rám vonatkozó nem verbális kijelentést.

Az igazán érdekes az, hogy miért ez az elhatárolódás, hiszen sok mindent legitimálhat az ember részvételével. Elôször is le kell szögeznem, hogy nem maga a víta meghirdetése, a kérdésfeltevés irritált. A vitát nagyon is idôszerūnek és szükségesnek tartom, és ennek aktualitását jelezte a nagyarányú részvétel is. Másodsorban pedig azt kell elmondanom, hogy nem is az egyéni megnyilatkozásokkal volt bajom, még akkor sem, ha némelyekkel alapvetóen nem értettem egyet. A megközelítések tarkasága, a vélemények szembenállása mind-mind szükségszerüen hozzátartoznak a tudományhoz. Nincs egyetlen olyan ismereti rendszer sem, amely a totalitás igényével léphetne fel, ezért minden igazi tudomány szükségszerüen pluralista. És az elméletet igénylốk sem az elméletet, az egyetlen magyarázó rendszert, hanem az elméleti megközelítést tartották szükségesnek.

Everything goes - ,Minden elmegy" - mondja Feyerabend. A pluralitás hangsúlyozása azonban nem azt jelenti, hogy minden megközelítéssel egyet is értek. Egyáltalán nem! Sem tényszerüségükben, sem értékszempontjaikat tekintve nem értek egyet bizonyos értékelésekkel. De most itt nem egyéni álláspontokkal szeretnék szembeszállni, hanem magával a vitával szembeni fenntartásaimról mondanám el véleményemet.

Ellenérzéseimet a vita szúkre szabott kommunikációs tere szülte. A leszúkített tér egy valamire, éspedig a rálátásra nem ad lehetổséget. Ezért aztán a jól hangsúlyozott részletek sem szolgálhatták igazán a konferencia céljának tekintett alapkérdés megválaszolását: van-e regionális tudomány. Igaz, nem azért vettem részt a tanácskozáson, hogy választ kapjak erre a kérdésre, hanem azért, mert úgy gondoltam, hogy feltehetjük a szakma alapvetó, egzisztenciális kérdéseit. Erre, úgy gondoltam, rendkívül nagy szükség van, és épp ezért ennek elmaradása okozta csalódásomat.

A kommunikációs tér beszû́küléséért már az első problémafelvetỗ előadás is felelổs (Faragó 1990). Anélkül, hogy kereste volna a választ a feltett alapkérdésre, kijelölte a gondolkodás terét. Öt kérdéscsoportba foglalta a megközelítés lehetséges irányait, úgymint elméleti, gyakorlati, metodikai, valamint a szakemberek és a tudomány rangját vizsgáló kérdéscsoportokba. Ezzel az aktussal a kérdés transzformációját hajtotta végre: a ,Van-e regionális gazdaságtan?" kérdést átcsúsztatta a ,Mi a regionális gazdaságtan?” kérdésébe. Nem kevésbé figyelemreméltó ez a kérdés sem, node nem ez volt feltéve. 
És ez, t.i. a kérdéstranszformációban rejlổ implicit válaszadás irritált. Annélkül, hogy körbejártuk volna a kérdést, megszületett a válasz : van regionális gazdaságtan, hiszen aminek van tárgya, metodikája, adatbázisa, (jól-rosszul) mû́ködổ rendszere, az van. A tudomány konszenzuson nyugszik, az tudomány, amit annak tartunk - tudjuk a tudományelméletból. Aki így véli, és mégis felteszi az alapkérdést, az a tudományt övezổ konszenzusra kérdez rá. A rákérdezés felettébb indokolt - érzékeltették a gyakorlati teendốk, hiszen az új szereplốk, az új struktúrák, a mélyülô válságok akkor is felvetnék a konszenzus újrateremtésének igényét, ha orvosságokban bổvelkedô, értékeiben biztos tudománnyal lenne dolgunk. De hát errôl nincs szó, épp a konszenzus megrendülésérốl árulkodik az utolsók között megfogalmazott kérdés, amelyik a tudomány rangját vetette fel.

Az már újabb kérdés, hogy a tudomány múvelổi önmagukban meg tudják-e oldani a konszenzus körüli problémákat a társtudományok vagy éppen a tudomány alanyai, szereplôi nélkül. Mindenesetre a konszenzust magát a vita nem állította középpontjába — noha mindvégig errốl volt szó -, amivel elkerülte az átvilágítás lehetổségét.

De mielổtt az átvilágítás tartalmi következményeibe merülnénk, térjünk vissza a prokrusztészi kommunikációs térre. A leszũkített tér azért problematikus, mert lezárja a valóságos kérdésfeltevések útját. Egy szaktudomány az illetékességi területét messze meghaladó kérdést tett fel önmagára nézve. Ez persze nagyon megtermékenyítỏ is lehet, a baj azonban az, hogy ezt egyedül önmaga akarta megválaszolni.

Ismeretelméleti, vagy tudományelméleti kérdést az ezzel foglalkozó tudományok eredményei, tapasztalatai nélkül.

Pedig, amint Heidegger mondja ,Egyetlen tudomány mint tudomány, azaz szigorúan véve mint tudomány, sem tudja megközelíteni saját alapfogalmait - s azt, amit ezen fogalmak megragadnak. Ez a tény azzal függ össze, hogy egyetlen tudomány sincs abban a helyzetben, hogy saját tudományos eszközeivel önmagáról is tehessen kijelentéseket. Az, hogy mi a matematika, sohasem deríthetổ ki matematikailag; az hogy mi a nyelvészet, sohasem fejthetổ ki nyelvészetileg; az hogy mi a biológia sohasem fejthetố ki biológiailag. Az tehát, hogy mi egy tudomány, már kérdésként nem tudományos kérdés többé. Abban a pillanatban, amikor feltesszük a kérdést, hogy egyáltalán mi a tudomány, ugyanakkor mindig a lehetséges meghatározott tudományokra kérdezünk rá, ezért a tudakozó új területekre lép át, amely más bizonyítékokat és bizonyítási formákat igényel, mint amelyeket a tudományok területén megszokottként ismernek el. Ez a filozófia területe. Nem emeletként húzzák rá a tudományokra, nem ragasztják hozzájuk. A filozófia maguknak a tudományoknak lényegébe van zárva, ezáltal érvényes a tétel: egy puszta tudomány csak oly mértékben tudományos, azaz valódi tudás s nem pusztán technikai hozzáértés, amilyen mértékben egyúttal filozófiai is."

A társtudományok nyújtotta átvilágítás nemcsak mint egyetlen lehetôség, nemcsak mint szellemi izgalom lett volna fontos a szakma számára, hanem rendkívül hasznos is lett volna. Talán kevesebb hivatkozás fordult volna elổ az újkori tudomány közhelyeire, talán kevesebb leszúkített értelmezés fordult volna elô! A tudományosság ismérvét a közgazdaságtanban talán nem a mérésben, a kvantifikációban vettük volna hallgatólagosan tudomásul (Bartke), hogy csak másra ne utaljak, mint Kornai zseniális összefüggéseire.

Esetleg tükörben láthattuk volna szaktudományunkat:

- hogy a tudományos elvek milyen hittételeken alapulnak; 
- hogy az ipari mintára szervezett kutatásban az empírikus, racionális megközelítésre való hivatkozás merổ látszat;

- hogy a kumuláció elve hamis, miszerint egyre többet ismerünk meg a területi folyamatokból, és hogy tudásunk egyre átfogóbbá válik;

- hogy csak áttételes a valóság és valóságkép közötti viszony;

- hogy a tények mindig teremtettek, elméletfüggók;

- hogy a tudományos kutatásban képviselt értékszempontok mindig elốzetes értékválasztáson alapulnak;

- hogy például a múhelyszervezổdések is a tudományon kívüli értékközösségekre épülnek. Lehetne hosszan sorolni egy tudományos paradigma elméleti és gyakorlati konzekvenciáit saját kutatásainkban, intézményi létünkben és legfốképp tudományos közéletünkben. Nem volna érdektelen kívülról látni a szakmát, legyen az regionális közgazdaságtan, vagy általánosabban véve regional science. De hagyjuk ezt a tudományelméletre, a filozófiára, akik hatékonyabban tudják alkalmazni a megközelítéshez szükséges fogalmi apparátust. Enélkül persze oldani kell a heidegger-i maxima érvényességét, azaz a kompetencia hiánya miatt a tudományt nem mint szigorúan vett tudományt vizsgáljuk. A tudomány áttekintése így viszont erốsen a szituációba ágyazott a résztvevốk személyén, praxisán, értékrendszerén, társadalmi és politikai nézetein, szerepvállalásán keresztül.

És itt visszatérünk a megroggyant konszenzus kapcsán felvetett átvilágítás kérdésére. Ha már feladtuk a tudomány létére vonatkozó alapkérdést, még vizsgálható lett volna a tudomány szituációja, azonban ehhez is relativizálni kellett volna igazságait, levetni az objektivitás álarcait, bevonni a vizsgálatba a résztvevốk meggyổzổéseit, azt a hatalmi, politikai és szellemi közeget, amiben mứködtek. Inkább használt, mintsem ártott volna ez a tudomány tekintélyének. Popper tudományetikai követelményrendszere a nem tudás beismerését alapkövetelménynek tekinti Kuhn és Feyerabend a tudománymítosz szétrombolásával, a tudomány relativizálásával a gondolkodás szabadságát adta vissza.

A társadalomföldrajz területén Beluszky már megindította szellemes esszéjével az öntisztázás folyamatát. Talán ez a vita is a vártnál korábban csendesült le, értékelése az ,átkok'-ról és következményeikrốl ma már ott van a társadalomföldrajz tudatalattijában. Az , ,átkok" kísértetiesen hasonlóak: a felvállalt udvari tanácsosi szerep, az anyatudománytól elszakadni nem tudó, identitás- és értékzavarban szenvedổ határtudományi lét és a szerény teljesítmény. A tér inkább csak kapcsoló közegként szerepel, az erre való hivatkozás gyakran csak a konzisztens értékrend hiányát leplezi, amely aztán az elméleti bázis gyengeségét eredményezi.

A tudományos értékrend centrális szerepére ráérzett Faragó is, aki egy posztmodern tudománykép értékeit állította az általa szorgalmazott helyi gazdaságfejlesztési elmélet és gyakorlat középpontjába: a lokális autonómiát, életminőségeszményt, a környezeti konfliktuskezelés alternatív módjait, a komplexitást és diverzitást, egy nem növekedés-, hanem társadalomcentrikus gazdaságot. Azonban az egyetértésre lehetôséget nyújtó tézisek sem feledtették, hogy az eddigi és a javasolt terápiák ellenére sincs képünk a betegségrốl, bár tüneteivel többé-kevésbé tisztában vagyunk.

A konzilium nem töltötte be feladatát. 


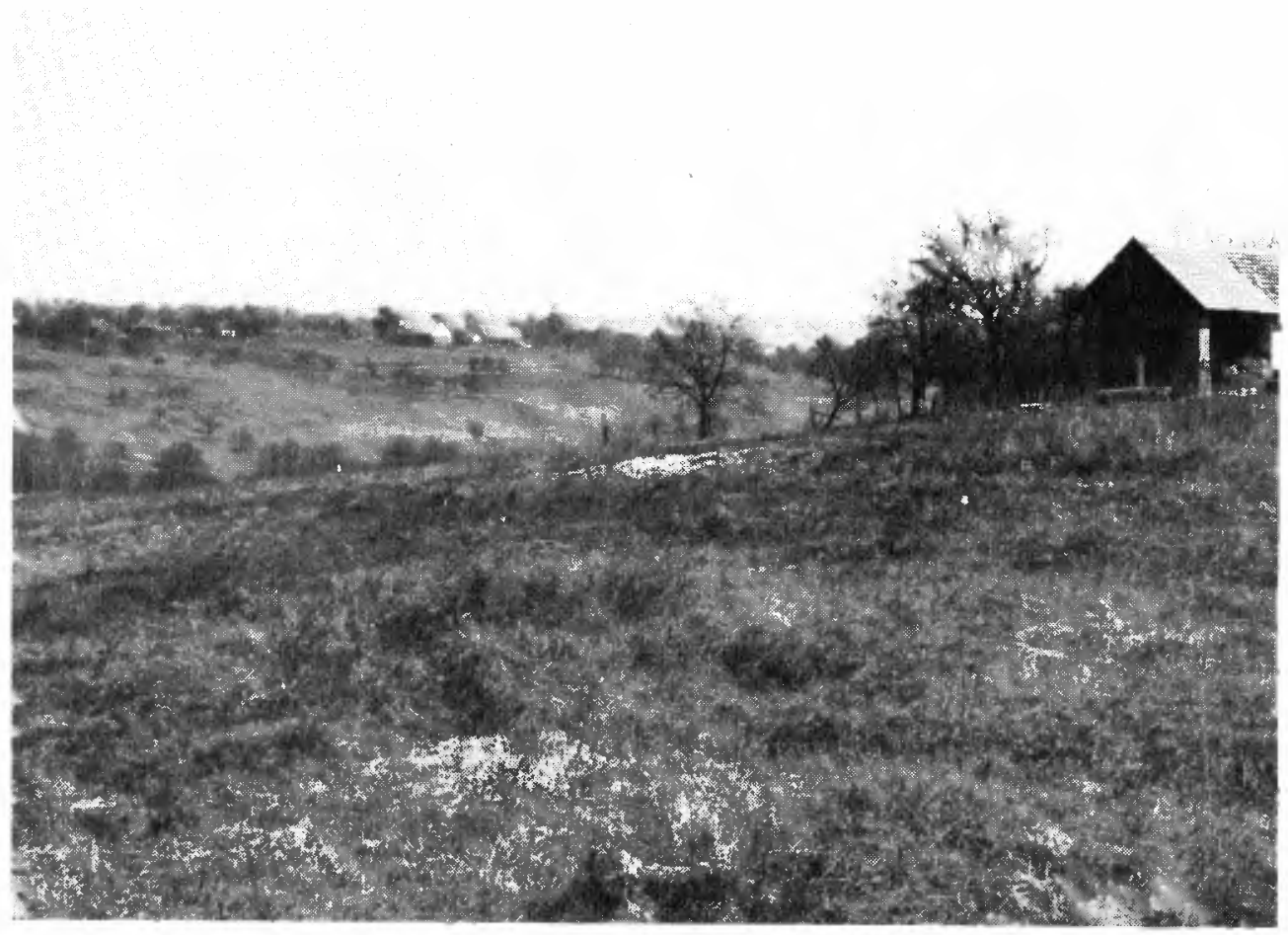

Szalafồ , parasztudvarok”. 